\title{
Trophic Niche Width, Shift, and Specialization of Dascyllus aruanus in Toliara Lagoon, Madagascar
}

\author{
Bruno Frédérich $^{1}$, Olivier Lehanse ${ }^{1}$, Pierre Vandewalle ${ }^{1}$, and Gilles Lepoint ${ }^{2}$
}

\begin{abstract}
Intrapopulation diet specializations may result from the use of different dietary items or foraging tactics by individuals within a single population. The damselfish, Dascyllus aruanus, is a highly site-attached coral reef fish living in size hierarchies among branched corals. The trophic niche width and feeding specialization of this species were explored using stable isotopes and stomach content analyses. Intra-group niche variation was mainly related to fish size. Within social groups, $D$. aruanus gradually shifted its foraging tactics according to size; smaller fish fed on benthic prey such as isopods and copepods, and the larger fish foraged in the water column on planktonic copepods and larger-sized prey. Group density was found to explain some variation in trophic niche characteristics; greater specialization on prey size was observed in the colony having the highest density. All members of the largest colony foraged more frequently in the water column. Knowing that planktonic copepods are more energy-rich than benthic ones, a positive group-size effect facilitating access to preferred prey is suggested. Group size and group density effects on trophic specialization did not have any impact on body condition, suggesting that the behavioral plasticity of $D$. aruanus in its foraging strategies permits compensation for the maintenance of body conditions.
\end{abstract}

$\mathrm{R}$ ECENTLY, some ecologists have focused on trophic niche width (or diet breadth) related to intrapopulation variations and their possible evolutionary implications (Bolnick et al., 2003). The diet breadth of animal populations form a continuum between two extremes: all individuals of the population are ecologically equivalent and use the same full set of food resources (no individual specialization), or the population is made up of specialized individuals that feed on a narrow range of resources and therefore the population diet breadth is determined by the addition of the different narrow niches of each individual (Bolnick et al., 2007). Specializations may result from the use of different dietary items or foraging tactics (Sargeant, 2007).

Schooling planktivorous species constitute one of the major guilds of the family Pomacentridae (Emery, 1973; Allen, 1991). Common throughout the tropical Indo-Pacific, the Humbug Damselfish, Dascyllus aruanus, typically belongs to this guild (Randall and Allen, 1977). It is a highly site-attached fish living in permanent social groups associated with branched corals (acroporan or pocilloporan corals) in which it shelters when threatened (Sale, 1971). The social groups usually consist of individuals of regular size gradations from small to large, where small fish are always subordinate to larger ones (Coates, 1980). This damselfish is generally regarded as a zooplanktivorous species that feeds on copepods and other planktonic prey (Randall and Allen, 1977). The size of prey taken by $D$. aruanus is influenced by social rank (Coates, 1980), and larger fish commonly feed further upstream than smaller ones (Forrester, 1991). At Toliara Reef, Madagascar, Frédérich et al. (2009) recently showed that benthic crustaceans might constitute a part of the diet of $D$. aruanus, enlarging the potential food niche of this species and allowing individuals a certain degree of diet variability or specialization.

In $D$. aruanus and other species living in stable social groups, diet breadth may be influenced by a combination of ontogenetic factors, dominance status, social group size, and social group composition (Forrester, 1991). All these factors may enhance individual diet specialization, potentially reducing resource competition between individuals within groups (Svanbäck and Bolnick, 2005). Intra-group competition linked to group size (Bednekoff and Lima, 2004) and group density (Svanbäck and Bolnick, 2007) could lead to a high degree of specialization among individuals, which could ultimately affect individual body condition. Such interactions may also be greater among animals living within a limited home range, such as highly site-attached coral reef fishes.

Here we used measurements of carbon and nitrogen isotopic ratios and stomach content analysis (i.e., prey type and size) to investigate the trophic niche width of the Humbug Damselfish in the Toliara Lagoon. Our first objective was to determine whether consumption of benthic prey represents an unexpected specialization related to variation in social group structure. Our second goal was to examine the possibility of individual diet specialization among $D$. aruanus and any relationships among group structure and individual specialization.

\section{MATERIALS AND METHODS}

Field sampling.-Five whole social groups (or colonies) of $D$. aruanus (total of 90 fish) were collected in the lagoon of the "Grand Récif" of Toliara (SW Madagascar, Mozambique Channel; $23.36^{\circ} \mathrm{S}, 43.66^{\circ} \mathrm{E}$ ) during October 2006 . The groups ranged in size from nine to 35 individuals (Table 1), and all occupied colonies of Acropora sp. at depths of 6 to $8 \mathrm{~m}$. The groups were located on the same site, $10 \mathrm{~m}$ away from each other, so the plankton supply was probably the same for the five colonies. Visual census during the five days preceding group capture showed that there was no immigration among coral heads by larger individuals. All specimens were collected between 0900 and $1100 \mathrm{hr}$ on the same day after being anesthetized with quinaldine. After their capture, fish were brought to the surface and killed as quickly as possible by immersion in MS-222 and placed on ice for return to the laboratory. Processing of fish involved measurement of standard length (SL) to the nearest $\mathrm{mm}$ and dissection to

\footnotetext{
${ }^{1}$ Laboratoire de Morphologie Fonctionnelle et Evolutive, Institut de Chimie (B6c), Université de Liège, B-4000 Liège, Belgium; E-mail: (BF) bruno.frederich@ulg.ac.be; (OL) olivierlehanse@yahoo.fr; and (PV) p.vandewalle@ulg.ac.be. Send reprint requests to BF.

${ }^{2}$ MARE, Laboratoire d'Océanologie, Institut de Chimie (B6c), Université de Liège, B-4000 Liège, Belgium; E-mail: (GL) g.lepoint@ulg.ac.be. Submitted: 4 February 2009. Accepted: 18 November 2009. Associate Editor: J. W. Snodgrass.
}

(c) 2010 by the American Society of Ichthyologists and Herpetologists DOI: 10.1643/CE-09-031 
Table 1. Composition of the Studied Social Groups (= Colony) of Dascyllus aruanus. $n$, number of fish; SL, standard length.

\begin{tabular}{|c|c|c|c|c|c|c|c|c|}
\hline & $n_{\text {total }}$ & $n_{\text {male }}$ & $n_{\text {female }}$ & $n_{\text {juvenile }}$ & density $\left(n / \mathrm{m}^{2}\right)$ & \multicolumn{3}{|c|}{$\mathrm{SL}(\mathrm{mm})$} \\
\hline Colony 1 & 9 & 2 & 3 & 4 & 20 & 37.3 & 49 & 27 \\
\hline Colony 3 & 18 & 4 & 8 & 6 & 44 & 38.2 & 56 & 24 \\
\hline Colony 4 & 18 & 2 & 4 & 12 & 34 & 33.7 & 50 & 20 \\
\hline Colony 5 & 35 & 3 & 9 & 23 & 73 & 31.1 & 47 & 17 \\
\hline
\end{tabular}

determine sexual status (juvenile, female, or male), collect samples (approx. $2 \mathrm{~cm}^{3}$ ) of lateral muscle tissue for stable isotope analysis, and extract entire digestive tracts to determine diet composition. We preserved and stored digestive tracts in $70 \%$ alcohol until stomach contents were examined and identified. Potential food sources such as zooplankton, benthic invertebrates (e.g., isopods and harpacticoid copepods), and turf algae were taken from the fish collection site according to the methodology described in Frédérich et al. (2009). Suspended organic matter was collected on a GF/C Whatman filter by pre-filtering five liters per sample of seawater from the collection site through a $250 \mu \mathrm{m}$ sieve and then through the filter paper. The coral heads occupied by each social group were measured to the nearest centimeter and their area was calculated. The densities of colonies of $D$. aruanus were expressed as fish $\mathrm{m}^{-2}$.

Stomach content analysis.-Fish stomachs $(n=90)$ were opened and all dietary constituents were dispersed onto individual glass slides. All food items were identified using a Leica M10 binocular microscope. Animal prey were identified to the level of family, class, or phylum and assigned to the planktonic or the benthic environment based on published descriptions (Trégouboff and Rose, 1978a, 1978b; Hayward and Ryland, 1995; Larink and Westheide, 2006) and field observations. Plant items were classified as either phytoplankton or fragments of benthic algae. Other items were classified as unrecognized. In order to define the breadth of the trophic niche of $D$. aruanus, we quantified food items in two ways: as a percentage of occurrence and as a mean percent composition of each item in the gut content (Hyslop, 1980). The null hypotheses of no difference in global foraging tactics among colony members was tested using a one-way ANOVA followed by post hoc multiple comparison tests (Tukey test). The data were arcsine-square root transformed before the analysis to meet the normality assumption (Shapiro Wilks' test, after transformation). The percentages of planktonic prey were regressed on the SL of fish to test the hypothesis of no relationship between foraging tactics and fish size.

We used an adaptation of Schoener's (1968) proportional similarity index $\left(\mathrm{PS}_{i}\right)$ in order to measure individual specialization of selected prey. This index measures the overlap between the diet of individual $i$ and the population diet (see Bolnick et al., 2002; Araújo and Gonzaga, 2007 for detailed explanations on this index). The $\mathrm{PS}_{i}$ values can be calculated for all individuals in the population and are summarized as a population-wide measure of individual specialization, IS, which is the average over all $\mathrm{PS}_{i}$ values (Bolnick et al., 2002). Individual specialization varies from near 0 (maximum individual specialization) to 1 (no individual specialization). To calculate this index, all food items were counted and divided into five categories (benthic algae, phytoplankton, sessile, vagile, and planktonic invertebrates) reflecting foraging constraints (Barel, 1983).

In order to measure individual specialization in prey size, the first 50 copepods (planktonic or benthic) encountered during the examination of stomach contents were measured to the nearest $10 \mu \mathrm{m}$ in all $D$. aruanus. This represents between 50 and $100 \%$ of stomach content items. Copepod sizes were used to test specialization on copepod size among colony members. Roughgarden's (1974) measure of individual specialization for continuous data, within-individual component (WIC)/total niche width (TNW), was used. The total niche width can be expressed as TNW $=\mathrm{WIC}+\mathrm{BIC}$, where TNW is the variance in size for all captured prey, WIC is the average variance of prey size used by individuals, and $\mathrm{BIC}$ is the between-individual component or variance among mean prey sizes of individual fish (Bolnick et al., 2003). The index WIC/TNW varies from 0 (maximum individual specialization) to 1 (no individual specialization).

The calculation of all indices of specialization was performed using the software IndSpec1 (Bolnick et al., 2002). We also used IndSpec1 to calculate the significance of individual specialization (WIC/TNW and IS measures) within each colony. IndSpec1 uses a nonparametric Monte Carlo procedure to generate replicate null diet matrices drawn from the population distribution from which $P$ values can be computed. We used 10,000 replicates in Monte Carlo bootstrap simulations. This nonparametric test was used because the data failed the test of normality (Shapiro Wilks' test). We tested a hypothetical variation of individual specialization related to group density and group size using correlation analyses.

Additionally, we examined prey size selectivity. We tested the null hypothesis of no relationship between fish size and copepod prey size using regression analysis. Comparisons of this relationship among colonies were carried out using an ANCOVA. We also incorporated sex status (juvenile, female, or male) as a second grouping factor in order to test how sex contributes to the pattern of covariation.

Stable isotope analysis.-Samples of lateral muscle tissue and potential food sources were dehydrated for at least $48 \mathrm{~h}$ at $50^{\circ} \mathrm{C}$ before being ground into a homogenous powder. After grinding, samples containing carbonates (turf algae and zoobenthos) were placed for $24 \mathrm{~h}$ under a glass bell with fuming $\mathrm{HCl}$ (37\%; Merck, for analysis quality) to eliminate calcareous material. Measurements were performed with a mass spectrometer (Optima, GV Instrument, UK) coupled to a C-N-S elemental analyzer (Carlo Erba, Italy) for combustion and automated analysis. Ratios are presented as $\delta$ values (\%), expressed relative to the vPDB (Vienna Peedee Belem- 
Table 2. Frequency of Occurrence $(\% \mathrm{~F})$ and Numerical Percentage $(\% \mathrm{~N})$ of All Dietary Categories in the Five Studied Social Groups of Dascyllus aruanus.

\begin{tabular}{|c|c|c|c|c|c|c|c|c|c|c|c|c|c|}
\hline \multirow{2}{*}{$\begin{array}{l}\text { Dietary categories } \\
\text { Planktonic preys }\end{array}$} & & \multicolumn{2}{|c|}{ Colony 1} & \multicolumn{2}{|c|}{ Colony 2} & \multicolumn{2}{|c|}{ Colony 3} & \multicolumn{2}{|c|}{ Colony 4} & \multicolumn{2}{|c|}{ Colony 5} & \multicolumn{2}{|c|}{$\begin{array}{l}\text { Pooled } \\
\text { colonies }\end{array}$} \\
\hline & & $\% \mathrm{~F}$ & $\% \mathrm{~N}$ & $\% \mathrm{~F}$ & $\% \mathrm{~N}$ & $\% \mathrm{~F}$ & $\% \mathrm{~N}$ & $\% \mathrm{~F}$ & $\% \mathrm{~N}$ & $\% \mathrm{~F}$ & $\% \mathrm{~N}$ & $\% \mathrm{~F}$ & $\% \mathrm{~N}$ \\
\hline \multirow[t]{5}{*}{ Copepods } & Harpacticoida & 33.3 & 0.4 & 80 & 1.4 & 38.9 & 0.5 & 82.4 & 1.5 & 84.4 & 2.4 & 66.3 & 1.5 \\
\hline & Calanoida & 100 & 20 & 100 & 5.3 & 100 & 24 & 100 & 35.9 & 100 & 18 & 100 & 22.4 \\
\hline & $\begin{array}{c}\text { Poecilostomatida } \\
\text { Coryceidae }\end{array}$ & 100 & 5.5 & 100 & 10.4 & 100 & 0.4 & 100 & 34.6 & 100 & 32.7 & 100 & 23.2 \\
\hline & Oncaeidae & 100 & 16.1 & 100 & 5.8 & 100 & 22.8 & 100 & 14 & 100 & 13.7 & 100 & 15 \\
\hline & «parasitic» & - & - & 20 & 0.2 & - & - & - & - & - & - & 2.3 & 0.02 \\
\hline Crustacean larvae & & 66.7 & 1.3 & 100 & 9.1 & 83.3 & 3.9 & 58.8 & 0.6 & 43.8 & 1.6 & 64 & 2.6 \\
\hline Ascidian larvae & & - & - & 20.2 & 0.2 & - & - & - & - & - & - & 2.3 & 0.02 \\
\hline Phytoplankton & & - & - & - & - & 16.7 & 0.8 & - & - & - & - & 3.5 & 0.2 \\
\hline Eggs & & 33.3 & 0.5 & - & - & 27.8 & 0.4 & 11.8 & 0.1 & - & - & 15.1 & 0.2 \\
\hline \multicolumn{14}{|l|}{ Benthic preys } \\
\hline Copepods & Harpacticoida & 100 & 50.2 & 100 & 64.9 & 100 & 29.6 & 100 & 9 & 96.9 & 28.6 & 98.8 & 30.1 \\
\hline Isopods & & 88.9 & 1.5 & 70 & 1.7 & 38.9 & 0.5 & 41.2 & 0.4 & 40.6 & 0.7 & 48.8 & 0.8 \\
\hline Halacarians & & - & - & 20 & 0.2 & - & - & - & - & 28.1 & 0.3 & 12.8 & 0.1 \\
\hline Ascidians & & 22.2 & 0.9 & - & - & 33.3 & 3.1 & 47.1 & 0.7 & 12.5 & 0.2 & 23.3 & 0.9 \\
\hline Algae & & 66.7 & 1.8 & - & - & 38.9 & 1.8 & 100 & 2.5 & 37.5 & 1.3 & 48.8 & 1.6 \\
\hline Fish scales & & 22.2 & 0.2 & - & - & 5.6 & 0.1 & 5.9 & 0.05 & - & - & 4.7 & 0.05 \\
\hline Unrecognized & & - & - & 40 & 0.8 & 16.7 & 0.2 & - & - & 6.3 & 0.1 & 10.5 & 0.2 \\
\hline
\end{tabular}

nite) standard and to atmospheric $\mathrm{N}_{2}$ for carbon and nitrogen, respectively. Reference materials were IAEA-N1 $\left(\delta^{15} \mathrm{~N}=+0.4 \pm 0.2 \%\right.$; mean $\left.\pm \mathrm{SD}\right)$ and IAEA CH-6 (sucrose; $\delta^{13} \mathrm{C}=-10.4 \pm 0.2 \%$; mean $\left.\pm \mathrm{SD}\right)$. Standard deviation on replicates of a $D$. aruanus pool was 0.3 and $0.4 \%$ for carbon and nitrogen, respectively.

An ANCOVA was performed in order to test the null hypothesis of the same covariation of $\delta^{13} \mathrm{C}$ and $\delta^{15} \mathrm{~N}$ among colonies. Linear regression analysis was used to examine trends of stable isotope composition with fish size (SL). As the social groups of $D$. aruanus are highly size-structured, we had to account for this factor in order to explore hypothetical variations in $\delta^{13} \mathrm{C}$ and $\delta^{15} \mathrm{~N}$ related to the group size of the colonies of $D$. aruanus. Therefore, we used an ANCOVA with fish size as the covariate, the isotope signature as the dependent variable, and colony as the group factor.

Estimate of body condition.-The $\mathrm{C} / \mathrm{N}$ ratio is used as a proxy to assess the body conditions of an individual because there are positive relationships between $\mathrm{C} / \mathrm{N}$ ratio of a tissue and lipid content for both aquatic and terrestrial animals (Post et al., 2007). We assume that lower lipid content in muscle is indicative of poor body condition. Regression analyses were used to investigate relationships between group size, group density, and mean individual body condition.

All statistical analyses were conducted using STATISTICA, version 7.1 (Statsoft, 2005). Before all ANCOVAs, homogeneity of variances between groups was always assessed by Cochran's test.

\section{RESULTS}

The largest fish was always a male (probably dominant) in each of the social groups studied. However, sex ratios or size range of individuals differed among colonies. Generally, social groups were composed of juveniles with the exception of colony 3, which housed more adult females than the others (Table 1).

Stomach content analysis.-Among all fish $(n=90)$, only four specimens had an empty stomach. The diet of $D$. aruanus consisted primarily of copepods (Table 2). Copepods accounted for more than $90 \%$ of the stomach content (pooled colonies) and included both planktonic (Calanoida, Harpacticoida, and Poecilostomatida) and benthic (Harpacticoida) forms. Benthic filamentous algae and ascidians were also sometimes grazed, but these generally represented less than $5 \%$ of the stomach items.

The proportions of planktonic copepods varied among the social groups of $D$. aruanus (Table 2; one-way ANOVA $F_{4,81}=$ 23.14; $P<0.01$ ). Pairwise comparisons revealed individuals of colonies 1 and 2 (i.e., the smallest ones) fed more on benthic crustaceans, such as harpacticoids and isopods, than did the members of the other colonies (post hoc Tukey test, $P<0.01$ ).

The diet of $D$. aruanus varied during growth, as shown by the strong relationships between fish size (SL) and the percentage of planktonic prey found in their stomach content (Fig. 1), though this relationship was not significant for colony $1\left(R^{2}=0.37 ; P=0.08\right)$. In each social group, the smaller fish (juveniles) fed more on benthic prey (Fig. 1), particularly harpacticoid copepods (Table 2). Adults fed generally on planktonic prey (Fig. 1).

Larger D. aruanus consume larger prey, as shown by the significant positive relationships between fish size and mean size of copepod prey $\left(R^{2} \geq 0.61\right.$; Fig. 2$)$. The ANCOVA revealed no differences in the slope of the regression model of each colony $\left(F_{4,76}=2.02 ; P=0.09\right)$. However, significant differences were present among the intercepts of the models $\left(F_{4,80}=50.59 ; P<0.01\right)$, probably related to the fact that planktonic copepods are larger than benthic copepods in the diets of $D$. aruanus. For example, all fish in colony 4 mainly fed on planktonic copepods. Consequently, they ingested on average larger preys than the members of other social groups. 

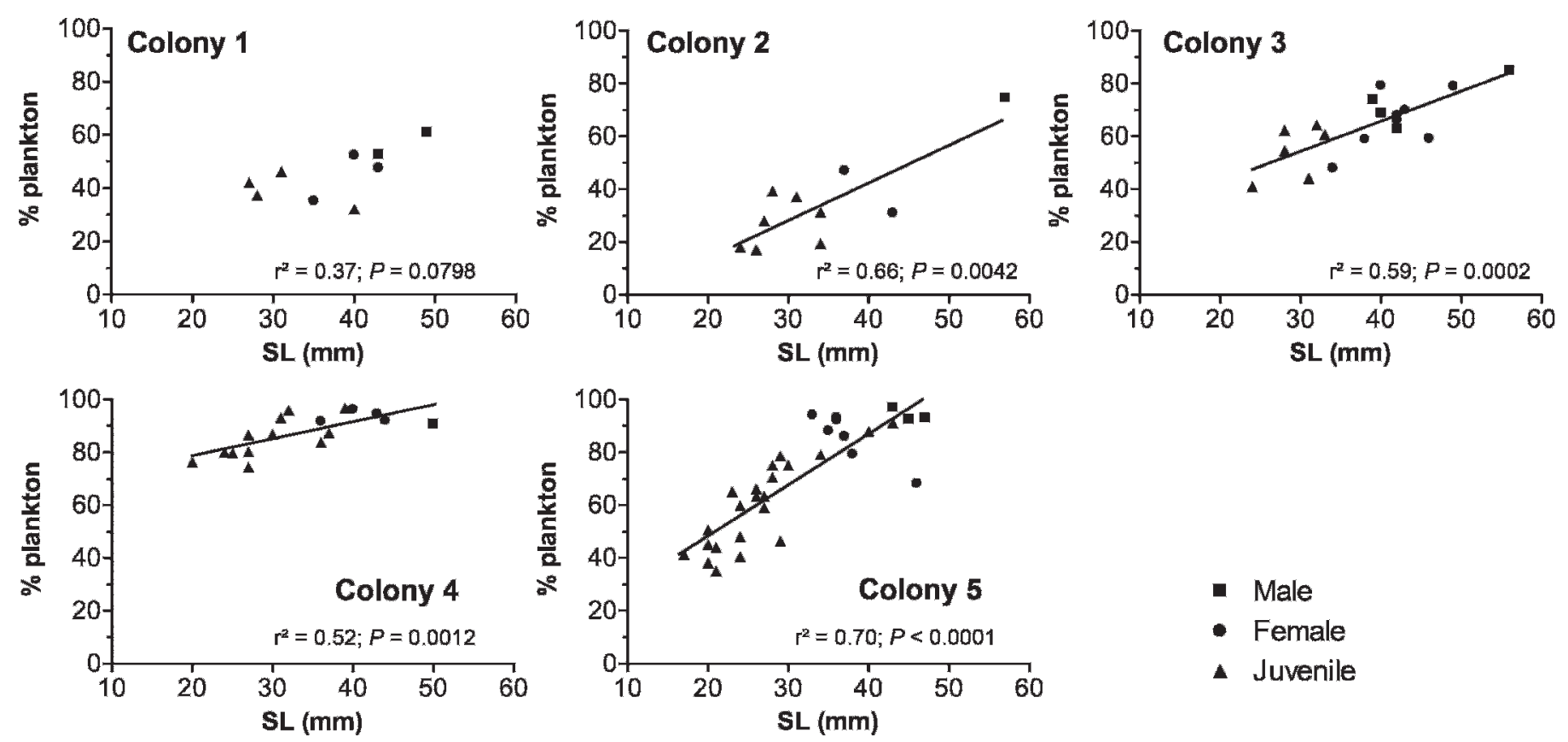

Fig. 1. Relationship between body size (SL) and proportion of planktonic prey in Dascyllus aruanus for the five colonies. Equation of regression models: colony $1, y=0.8 x+16.6$; colony $2, y=1.4 x-14.16$; colony $3, y=1.1 x+20.4$; colony $4, y=0.6 x+66 ;$ colony $5, y=1.9 x+10.4$.

Sex status did not influence covariation between fish size and ingested copepod size (test of common slopes: $F_{2,74}=$ $0.56 ; P=0.58$; homogeneity of intercepts: $F_{2,78}=0.39 ; P=$ 0.68). However, the biggest male always fed on the largest sized prey (Fig. 2).

Among colonies IS varied between 0.80 and 0.88 (Table 3 ), indicating weak but significant specialization on prey types (five functional groups) within social groups. The index of specialization was not significantly related to the size $(R=$ 0.06; $P=0.92)$ or the density of colonies $(R=0.32 ; P=$ $0.60)$. On the other hand, a significant negative relationship between individual specialization in prey size (WIC/TNW) and density of social groups was observed $(R=-0.95 ; P=$ 0.01 ; Fig. 3$)$. The relationship between WIC/TNW and group size was similar but not significant $(R=-0.85 ; P=0.06)$. Group size, and especially group density, drove individual specialization, but these tests should be interpreted cautiously given the sample size $(n=5)$.

No correlation was found between WIC/TNW and variance in fish size within colonies $(R=-0.25)$. Consequently, the effect of ontogeny on the WIC/TNW variation among social groups was negligible. A decrease in the WIC/ TNW index related to the group density was not linked to an increase in the TNW $(R=-0.09, P=0.88)$. However, the
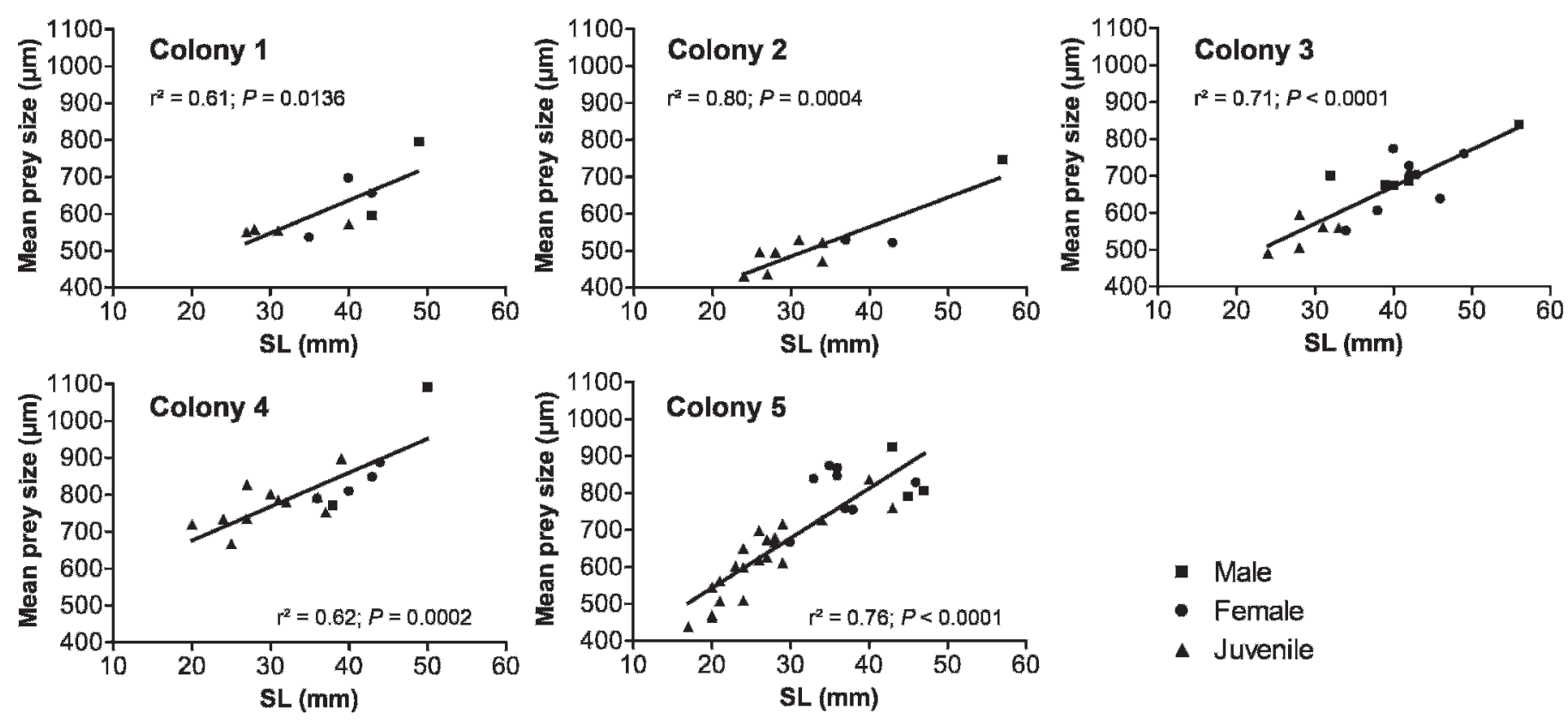

Fig. 2. Relationship between body size (SL) and mean copepod size in Dascyllus aruanus for the five colonies. Equation of regression models: colony $1, y=8.9 x+280$; colony $2, y=8.0 x+250 ;$ colony $3, y=10 x+270 ;$ colony $4, y=9.2 x+490 ;$ colony $5, y=13 x+270$. 
Table 3. Specialization on Prey Groups (IS) and Prey Size (WIC/TNW) between Colonies. The significance of individual specialization within each colony (IS and WIC/TNW measures) was calculated by a Monte Carlo bootstrap simulations $(n=10,000)$.

\begin{tabular}{lccccccc}
\hline & IS & $P$ & BIC & WIC & TNW & WIC/TNW & $P$ \\
\hline Colony 1 & 0.8024 & $<0.001$ & 3,220 & 63,130 & 67,410 & 0.9365 & 0.0014 \\
Colony 2 & 0.8785 & $<0.001$ & 6,917 & 33,300 & 39,220 & 0.8491 & $<0.001$ \\
Colony 3 & 0.8493 & $<0.001$ & 8,760 & 42,470 & 53,710 & 0.7907 & $<0.001$ \\
Colony 4 & 0.8553 & $<0.001$ & 8,292 & 51,550 & 59,870 & 0.8609 & $<0.001$ \\
Colony 5 & 0.8425 & $<0.001$ & 20,620 & 46,960 & 67,350 & 0.6972 & $<0.001$ \\
\hline
\end{tabular}

BIC (variance among mean prey size for individual fish) increased significantly with group density $(R=0.97 ; P<$ $0.01)$.

Stable isotope data.-Turf algae and zoobenthos had lower $\delta^{15} \mathrm{~N}$ values than $D$. aruanus, ranging from 3 to $6 \%$ (Fig. $4 \mathrm{~A}$ ). Zooplankton had lower $\delta^{13} \mathrm{C}$ and higher $\delta^{15} \mathrm{~N}$ than both algae and zoobenthos. The $\delta^{13} \mathrm{C}$ values in $D$. aruanus ranged from -17 to $-15.4 \%$ and the $\delta^{15} \mathrm{~N}$ values from 7.8 to $10.1 \%$ (Fig. 4).

The covariation of $\delta^{13} \mathrm{C}$ and $\delta^{15} \mathrm{~N}$ did not significantly differ among social groups (ANCOVA $F_{4,78}=0.37 ; P=0.83$ ). The range of $\delta^{13} \mathrm{C}$ was relatively low within each colony (0.2-0.6\% according to the colony; Fig. $4 \mathrm{~B})$, while the variation of $\delta^{15} \mathrm{~N}$ was higher $(0.8-1.3 \%)$. The variation of $\delta^{13} \mathrm{C}$ in $D$. aruanus was weakly related to size (when all colonies are pooled; $R^{2}=0.25 ; P<0.01$ ), where smaller individuals showed the lowest $\delta^{13} \mathrm{C}$ values. On the other hand, in each colony there was a significant positive relationship between fish size and $\delta^{15} \mathrm{~N}\left(0.55 \leq R^{2} \leq 0.74\right.$; Fig. 5). The ANCOVA revealed no differences between the slopes of the regression models $\left(F_{4,78}=1.32 ; P=0.27\right)$, indicating that the rate of enrichment in ${ }^{15} \mathrm{~N}$ with fish size was similar among social groups. On the other hand, ANCOVA revealed differences between the intercepts of the regression models $\left(F_{4,82}=9.94 ; P<0.01\right)$, revealing significant differences between $\delta^{15} \mathrm{~N}$ values among social groups when the effect of fish size is excluded. No clear relation existed between the intercept values $\left(\delta^{15} \mathrm{~N}\right.$ when size $=0)$ and the group size. However the three colonies having the highest density (i.e. colony 2, 3, and 5) showed the highest value of $\delta^{15} \mathrm{~N}$ (intercept values: $7.7_{\text {(colony 2) }}>7.6_{(\text {col. 3) }}$ $\left.>7.4_{(\text {col. } 5)}>6.7_{(\text {col. } 4,1)}\right)$.

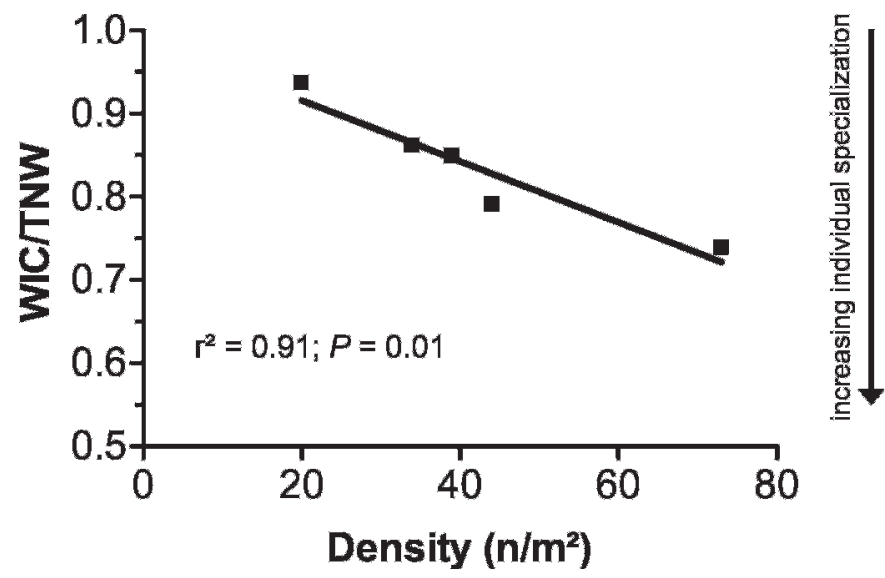

Fig. 3. Effect of group density on trophic specialization on prey size measured with WIC/TNW in Dascyllus aruanus. WIC = within-individual component, TNW = total niche width.
Pearson correlation analysis revealed significant (except for colony $2, P=0.15$ ) positive relationships between $\delta^{15} \mathrm{~N}$ values of $D$. aruanus and the abundance of zooplankton in their stomach $(0.53 \leq R \leq 0.81$ according to the social group; Fig. 6). This result confirmed that higher $\delta^{15} \mathrm{~N}$ values reflect a higher proportion of zooplankton or different type of zooplankton in the diet of the larger $D$. aruanus, or both.

Individual body condition.-No significant linear relationships existed between the means of body condition $(\mathrm{C} / \mathrm{N})$ and group size $\left(R^{2}=0.0003, P=0.98\right)$ or group density $\left(R^{2}=\right.$ $0.02, P=0.82$ ). Although variation was limited (Table 4$)$, the $\mathrm{C} / \mathrm{N}$ ratio differed significantly between the five colonies (ANOVA $F_{4,82}=16.30 ; P<0.01$ ). Social groups 3 and 4 showed significantly higher $\mathrm{C} / \mathrm{N}$ values than the other colonies (post hoc Tukey test, $P<0.01$ ). Variance in body condition within social groups was also not correlated with colony size or density $(R<0.45, P>0.2)$.

\section{DISCUSSION}

Dascyllus aruanus is generally considered a typically zooplanktivorous damselfish (Coates, 1980; Forrester, 1991; Kuo and Shao, 1991), but the present study opens new perspectives on its trophic ecology. At Toliara Reef, variation in feeding behavior and diet specialization were highlighted within and among social groups of $D$. aruanus.

Intra-group variation.-In this study, individual specialization within social groups was shown to be relatively low. The majority of intra-group variation was mainly sizerelated. Our results confirm the statement that body size of fish is often correlated with $\delta^{15} \mathrm{~N}$ (Matthews and Mazumder, 2005). This relationship may be interpreted as an ontogenetic shift to higher trophic positions (Reñones et al., 2002), shift in habitat use (Genner et al., 2003), or temporal variability of food sources (Matthews and Mazumder, 2005). In our study, the stomach content analyses reveal that variation in $\delta^{15} \mathrm{~N}$ corresponded to ontogenetic diet changes in the type (benthic vs. planktonic) and the size of prey. During growth, D. aruanus gradually shifts its foraging tactics so that smaller fish feed on benthic prey, such as isopods and copepods, larger fish forage in the water column on planktonic copepods, and larger fish consume larger prey. Our results can now explain why larger $D$. aruanus (Forrester, 1991; Booth, 2004) and D. albisella (Mann and Sancho, 2007) are usually found feeding further off the coral patch than smaller individuals. This size-related trophic shift could be viewed as a foraging specialization within the social group. This behavioral specialization during growth is probably driven by a combination of extrinsic (i.e. predation, competition) and intrinsic (morphology and physiology) factors. Morphologically, the 

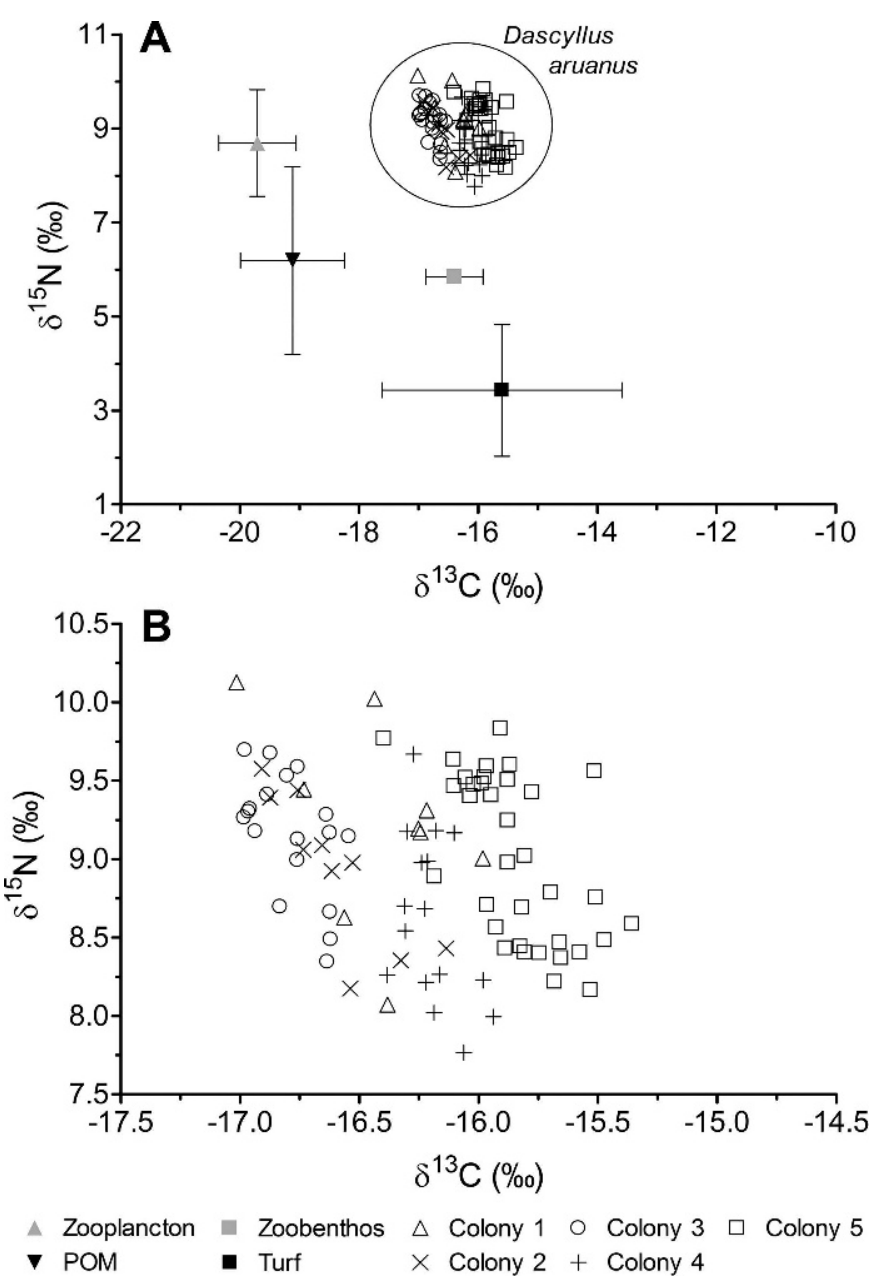

Fig. 4. (A) Mean ( \pm SD) $\delta^{15} \mathrm{~N}$ and $\delta^{13} \mathrm{C}$ ratios of food items collected from the lagoon and isotope values of all Dascyllus aruanus. (B) $\delta^{15} \mathrm{~N}$ and $\delta^{13} \mathrm{C}$ ratios of each $D$. aruanus in the five colonies. influence of oral anatomy and mouth size on prey size is evident (Luczkovich et al., 1995). An enhanced suction feeding ability (Frédérich et al., 2008) and more efficient vision for planktonic prey (Losey et al., 2000) has evolved among $D$. aruanus and $D$. albisella, respectively. Moreover, larger fish can probably swim faster, so they can feed farther from the coral head with no increase in the time required to swim back for sheltering (Webster and Hixon, 2000).

Our results show that the size of prey selected by the other members of the colony is determined by fish size and not by sex status. Within groups, the dominant male (the largest) always has access to the largest planktonic copepods (Coates, 1980; Forrester, 1991; present study). Recently, the adaptive significance of structured size hierarchies has been questioned in clownfishes (Buston and Cant, 2006). A primary cause suggested was the resolution of potential conflict over group membership between individuals adjacent in rank (Buston, 2003; Buston and Cant, 2006). However, the present study reveals another cause or consequence of size hierarchies, where highly size-structured groups can offer the advantage of reducing possible intra-group trophic competition in association with sizerelated diet shift and specialization.

Inter-group variation.-Variation among colonies in trophic niche width was relatively low, and, therefore, the trophic niche of individual social groups completely overlapped the trophic niche of the population of $D$. aruanus to which they belonged. However, although our results should be interpreted cautiously given our sample size $(n=5)$, colonies showed some evidence of density dependent diet specialization among groups.

In $D$. aruanus, the increase in individual specialization on prey size does not occur by extended total niche width (TNW). Indeed, in addition to functional constraints, the extremely limited home range of $D$. aruanus and its behavior reduce the possibilities of TNW expansion by new foraging
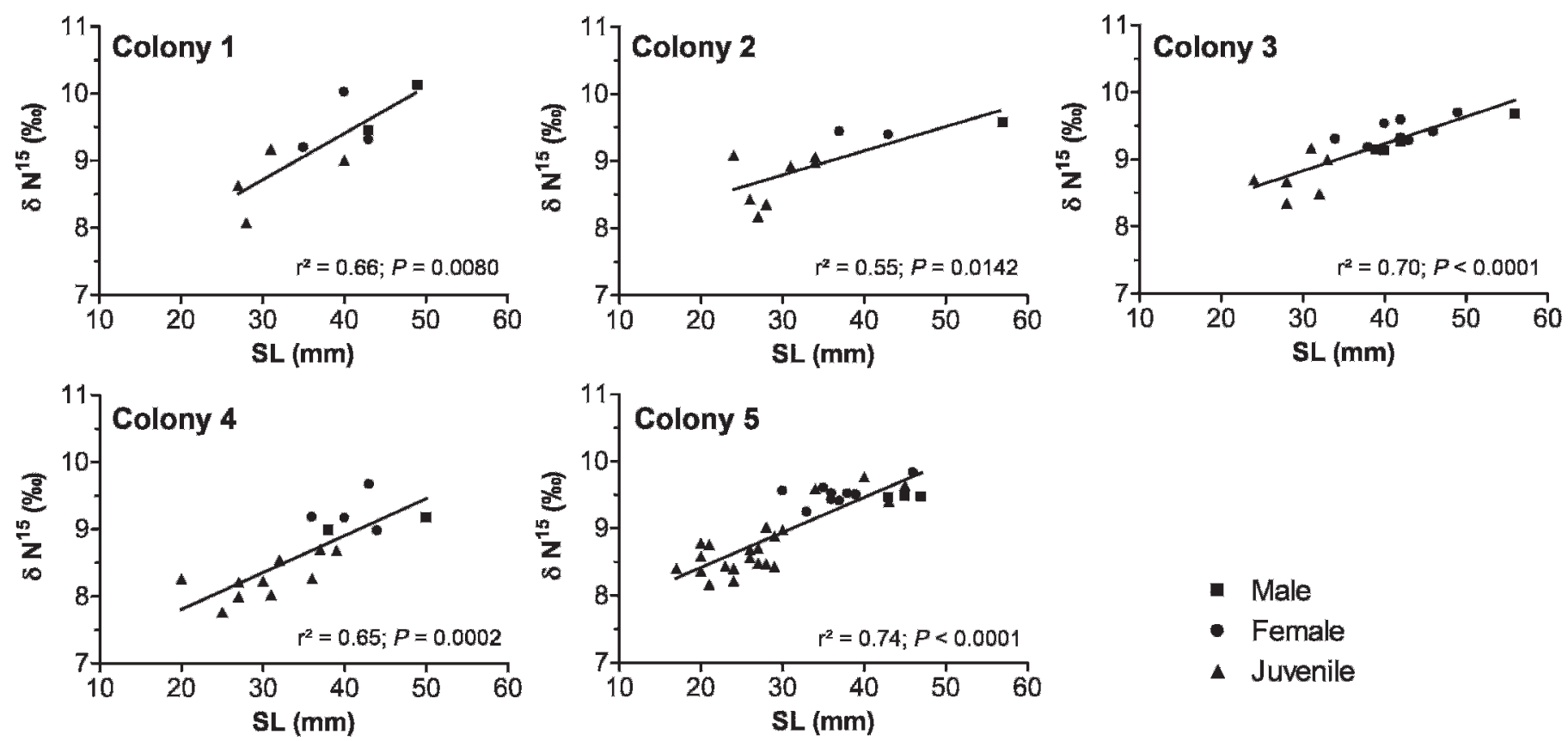

Male

Fig. 5. Relationship between body size (SL) and $\delta^{15} \mathrm{~N}$ values in Dascyllus aruanus for the five colonies. Equation of regression models: colony $1, y=$ $0.07 x+6.7$; colony $2, y=0.04 x+7.7 ;$ colony $3, y=0.04 x+7.6 ;$ colony $4, y=0.05 x+6.7 ;$ colony $5, y=0.05 x+7.4$. 

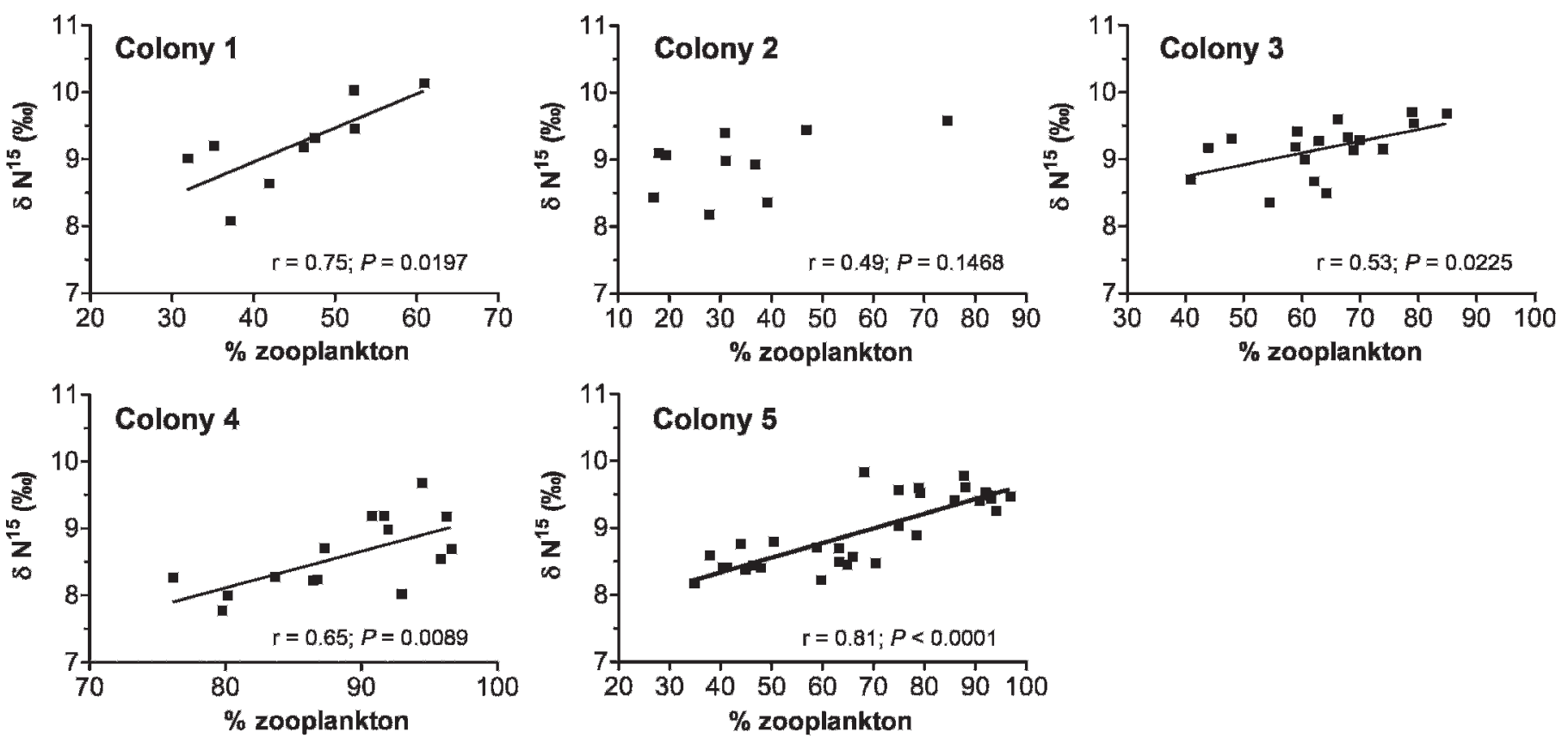

Fig. 6. Correlations between $\delta^{15} \mathrm{~N}$ values and the proportion of planktonic prey present in the stomach of each Dascyllus aruanus in the five colonies.

activities. The average long-term diet within a colony of $D$. aruanus is size-related and stable over time. However, the results also provide some evidence of variation in this pattern between social groups, which could be related to differences in group densities and to a lesser extent, group sizes.

A greater specialization in prey size selectivity was revealed in $D$. aruanus belonging to social groups of high density (Fig. 3). The inter-group specialization in prey types (i.e., benthic vs. planktonic prey) is weak as it is primarily determined by intra-group specialization. Nevertheless, variation in inter-group specialization also appears to be enhanced by variation in group densities. The level of intragroup competition or social interactions within groups, or both, could be linked to group density, leading to increased division of the resources among all individuals within the colony (Svanbäck and Bolnick, 2007). Increased population density drives increased inter-individual variation in diet (BIC) so that fish forage more selectively when group density increases. Specialization in prey size defined by the WIC/TNW index in Anolis (Iguanidae) has been shown to range between 0.67 and 0.98 (Bolnick et al., 2003). In comparison with these studies, the specialization on prey size in D. aruanus is defined by similar values. Unfortunately, the possibility of comparison remains limited due to the lack of similar studies using the same index.

Table 4. Individual Body Condition $(\mathrm{C} / \mathrm{N})$ within the Studied Social Groups of Dascyllus aruanus.

\begin{tabular}{lc}
\hline & $\mathrm{C} / \mathrm{N}($ mean $\pm \mathrm{SD})$ \\
\hline Colony 1 & $3.240 \pm 0.055$ \\
Colony 2 & $3.218 \pm 0.044$ \\
Colony 3 & $3.371 \pm 0.072$ \\
Colony 4 & $3.331 \pm 0.097$ \\
Colony 5 & $3.239 \pm 0.057$ \\
\hline
\end{tabular}

Planktonic copepods are more energy-rich than those in the benthos (Clarke, 1999), probably due to their higher lipid content (Sargent and Falk-Petersen, 1988), so D. aruanus may face a choice between a risky, high-profit food source and a safer, less profitable one. One benefit of group membership is reduced predation risk (Booth, 1995; Kent et al., 2006), where a greater level of safety is expected in larger groups due to some combination of simple risk dilution and collective threat detection (Beauchamp, 2003; White and Warner, 2007). The stomach content analysis showed that individuals of the smaller social groups (colony 1 and 2) feed more on benthic copepods and isopods (Table 2). This snapshot observation was not reflected in isotope analyses. On the other hand, the colony having the highest density (colony 2, 3, and 5) showed the highest $\delta^{15} \mathrm{~N}$ values (ANCOVA, Fig. 5). Knowing that zooplankton had higher $\delta^{15} \mathrm{~N}$ than zoobenthos (Fig. 4), isotopic results suggest that the majority of the members of these three social groups should remain more permanently in the water column foraging on planktonic prey. Behavioral variation in social groups may reflect the combined effects of predation risk and prey availability (White and Warner, 2007). The density of colonies 1,2 , and 4 was lower than that of the others. Consequently, its members have a larger benthic foraging area per fish, giving direct access to a safer, but poorer source of food. The members of the smallest colonies could feed more readily on benthic prey or on prey thriving close to their branched coral, although they would opportunistically forage in the water column. The foraging behavior of $D$. aruanus could also be linked to the intra-group competition. Indeed, a more risky foraging behavior in large social groups could be a response to resource competition.

Group size and density could increase intra-group competition, potentially affecting feeding success, growth, body condition, or fecundity. For example, reduced growth rate was a cost of group living among Domino Damselfish juveniles (Dascyllus albisella; Booth, 1995) and Bluehead Wrasse recruits (Thalassoma bifasciatum; White and Warner, 
2007). Among D. marginatus, feeding success is greater among fish living in small groups (Kent et al., 2006). Bluehead Wrasse settlers living in groups spend more time feeding in the plankton, but obtain less food (White and Warner, 2007). Interestingly, the inter-group variation in trophic specialization induced little difference in mean body condition among $D$. aruanus. The behavioral plasticity of $D$. aruanus in foraging strategies may compensate for differences in group composition, allowing maintenance of body conditions. These observations support the data of Booth (2004), where higher body energy reserves were observed in the juveniles of $D$. aruanus experimentally placed with adults. Indeed, knowing that settlers prefer branching corals occupied by conspecifics (Sweatman, 1983), the newly settled juveniles probably benefit from the experiences in feeding strategies of their conspecifics.

Variation between and within coral reef ecosystems.-In the Red Sea, D. marginatus living in smaller groups (of one to three fish) have been found to show a two-fold higher feeding success rate than those in large groups ( $\geq 10$ fishes; Kent et al., 2006). This finding may appear contrary to our suggestion regarding the positive effect of living in larger social groups in D. aruanus. However, in D. marginatus, $<5 \%$ of groups consist of more than ten fish (Kent et al., 2006). In the Gulf of Aqaba, very few D. aruanus (6\%) are found in groups of more than six fish, the others living in heterosexual pairs $(38 \%)$ or in aggregates of three to six fish $(56 \%$; Fricke and Holzberg, 1974). On the other hand, large social groups of $D$. aruanus (10-30 individuals/colony) are very common in the lagoon of Toliara, an area that is characterized by high zooplankton biomass and high suspended particle concentrations (BF, pers. obs.) in comparison with the oligotrophic Red Sea (Klinker et al., 1978). These data illustrate a common pattern in the distribution of social group size in D. aruanus and D. marginatus in the Red Sea, which appears to be quite different from the one at Toliara. Consequently, other ecological constraints (i.e., branched coral size, plankton availability, or plankton flux; Noda et al., 1992) may shape the ecological advantage of group size in Dascyllus species. These geographical differences in $D$. aruanus provide further evidence of the adaptive advantage of ecological plasticity of trophic strategies in this widespread species. Ecological plasticity may also occur at smaller scales, as $D$. aruanus is found across multiple reef zones. Moreover, temporal variation in food availability (i.e., season) could also influence plasticity.

In conclusion, this study illustrates that planktivorous $D$. aruanus also forage on benthic crustaceans close to the corals. Using current methods in trophic niche studies (variance in stable isotopes, measures of specialization), we show how and to what extent the diet of a highly siteattached coral reef fish living in groups may vary. Although its trophic habitat seems limited (a coral head), D. aruanus shows specialization and behavioral adaptations to local ecological constraints.

\section{ACKNOWLEDGMENTS}

We thank J.-M. Ouin, Prosper, Noëlson, the Aqua-Lab team, and the Institut Halieutique et des Sciences Marines of the Toliara University for helping to collect the fishes and for providing hospitality and laboratory facilities. The authors also thank P. Dauby, M. Poulicek, and J.-H. Hecq for their useful comments on copepod biology. The authors thank C.
Joaquim-Justo and P. Smith for linguistic assistance. This study was funded by the Belgian National Fund for Scientific Research (FRS-FNRS; FRFC contract no. 2.4.583.05). This paper is the MARE paper number 176.

\section{LITERATURE CITED}

Allen, G. R. 1991. Damselfishes of the World. Mergus, Germany.

Araújo, M. S., and M. O. Gonzaga. 2007. Individual specialization in the hunting wasp Trypoxylon (Trypargilum) albonigrum (Hymenoptera, Crabronidae). Behavioral Ecology and Sociobiology 61:1855-1863.

Barel, C. D. N. 1983. Towards a constructional morphology of cichlid fishes (Teleostei, Perciformes). Netherlands Journal of Zoology 33:357-424.

Beauchamp, G. 2003. Group-size effects on vigilance: a search for mechanisms. Behavioural Processes 63:111121.

Bednekoff, P. A., and S. L. Lima. 2004. Risk allocation and competition in foraging groups: reversed effects of competition if group size varies under risk of predation. Proceedings of the Royal Society B Biological Sciences 271:1491-1496.

Bolnick, D. I., R. Svanbäck, M. S. Araújo, and L. Persson. 2007. Comparative support for the niche variation hypothesis that more generalized populations also are more heterogeneous. Proceedings of the National Academy of Sciences of the United States of America 104:10075-10079.

Bolnick, D. I., R. Svanbäck, J. A. Fordyce, L. H. Yang, J. M. Davis, C. D. Hulsey, and M. L. Forister. 2003. The ecology of individuals: incidence and implications of individual specialization. The American Naturalist 161:1-28.

Bolnick, D. I., L. H. Yang, J. A. Fordyce, J. M. Davis, and R. Svanbäck. 2002. Measuring individual-level resource specialization. Ecology 83:2936-2941.

Booth, D. J. 1995. Juvenile groups in a coral-reef damselfish: density-dependent effects on individual fitness and population demography. Ecology 76:91-106.

Booth, D. J. 2004. Synergistic effects of conspecifics and food on growth and energy allocation of a damselfish. Ecology 85:2881-2887.

Buston, P. M. 2003. Size and growth modification in clownfish. Nature 424:145-146.

Buston, P. M., and M. A. Cant. 2006. A new perspective on size hierarchies in nature: patterns, causes, and consequences. Oecologia 149:362-372.

Clarke, R. D. 1999. Diets and metabolic rates of four Caribbean tube blennies, genus Acanthemblemaria (Teleostei: Chaenopsidae). Bulletin of Marine Science 65: 185-199.

Coates, D. 1980. Prey-size intake in humbug damselfish, Dascyllus aruanus (Pisces, Pomacentridae) living within social groups. Journal of Animal Ecology 49:335-340.

Emery, A. R. 1973. Comparative ecology and functional osteology of fourteen species of damselfish (Pisces: Pomacentridae) at Alligator Reef, Florida Keys. Bulletin of Marine Science 23:649-770.

Forrester, G. E. 1991. Social rank, individual size and group composition as determinants of food consumption by humbug damselfish, Dascyllus aruanus. Animal Behaviour 42:701-711. 
Frédérich, B., D. Adriaens, and P. Vandewalle. 2008. Ontogenetic shape changes in Pomacentridae (Teleostei, Perciformes) and their relationships with feeding strategies: a geometric morphometric approach. Biological Journal of the Linnean Society 95:92-105.

Frédérich, B., G. Fabri, G. Lepoint, P. Vandewalle, and E. Parmentier. 2009. Trophic niches of thirteen damselfishes (Pomacentridae) at the Grand Récif of Toliara, Madagascar. Ichthyological Research 56:10-17.

Fricke, H. W., and S. Holzberg. 1974. Social units and hermaphroditism in a pomacentrid fish. Naturwissenschaften 61:367-368.

Genner, M. J., S. J. Hawkins, and G. F. Turner. 2003. Isotopic change throughout the life history of a Lake Malawi cichlid fish. Journal of Fish Biology 62:907-917.

Hayward, P. J., and J. S. Ryland. 1995. Handbook of the Marine Fauna of North-West Europe. Oxford University Press, New York.

Hyslop, E. J. 1980. Stomach contents analysis-a review of methods and their application. Journal of Fish Biology 17:411-429.

Kent, R., R. Holzman, and A. Genin. 2006. Preliminary evidence on group-size dependent feeding success in the damselfish Dascyllus marginatus. Marine Ecology Progress Series 323:299-303.

Klinker, J., Z. Reiss, C. Kropach, I. Levanon, H. Harpaz, and Y. Shapiro. 1978. Nutrients and biomass distribution in the Gulf of Aqaba (Elat), Red Sea. Marine Biology 45:53-64.

Kuo, S. R., and K. T. Shao. 1991. Feeding habits of damselfish (Pomacentridae) from the southern part of Taiwan. Journal of the Fisheries Society of Taiwan 18:165-176.

Larink, O., and W. Westheide. 2006. Coastal Plankton. Photo Guide for European Seas. Verlag, München.

Losey, G. S., P. A. Nelson, and J. P. Zamzow. 2000. Ontogeny of spectral transmission in the eye of the tropical damselfish, Dascyllus albisella (Pomacentridae), and possible effects on UV vision. Environmental Biology of Fishes 59:21-28.

Luczkovich, J. J., S. F. Norton, and R. G. Gilmore, Jr.. 1995. The influence of oral anatomy on prey selection during the ontogeny of two percoid fishes, Lagodon rhomboides and Centropomus undecimalis. Environmental Biology of Fishes 44:79-95.

Mann, D. A., and G. Sancho. 2007. Feeding ecology of the domino damselfish, Dascyllus albisella. Copeia 2007: 566-576.

Matthews, B., and A. Mazumder. 2005. Consequences of large temporal variability of zooplankton $\delta^{15} \mathrm{~N}$ for modeling fish trophic position and variation. Limnology and Oceanography 50:1404-1414.

Noda, M., K. Kawabata, K. Gushima, and S. Kakuda. 1992. Importance of zooplankton patches in foraging ecology of the planktivorous reef fish Chromis chrysurus (Pomacentridae) at Kuchinoerabu Island, Japan. Marine Ecology Progress Series 87:251-263.

Post, D. M., C. A. Layman, D. A. Arrington, G. Takimoto, J. Quattrochi, and C. G. Montana. 2007. Getting to the fat of the matter: models, methods and assumptions for dealing with lipids in stable isotope analyses. Oecologia 152:179-189.

Randall, H. A., and G. R. Allen. 1977. A revision of the damselfish genus Dascyllus (Pomacentridae) with the description of a new species. Records of the Australian Museum 31:349-385.

Reñones, O., N. V. C. Polunin, and R. Goni. 2002. Size related dietary shifts of Epinephelus marginatus in a western Mediterranean littoral ecosystem: an isotope and stomach content analysis. Journal of Fish Biology 61:122-137.

Roughgarden, J. 1974. Niche width, biogeographic patterns among Anolis lizard populations. The American Naturalist 108:683-718.

Sale, P. 1971. Extremely limited home range in a coral reef fish Dascyllus aruanus. Copeia 1971:324-327.

Sargeant, B. L. 2007. Individual foraging specialization: niche width versus niche overlap. Oikos 116:1431-1437.

Sargent, J. R., and S. Falk-Petersen. 1988. The lipid biochemistry of calanoid copepods. Hydrobiologia 167168:101-114.

Schoener, T. W. 1968. The Anolis lizards of Bimini: resource partitioning in a complex fauna. Ecology 49:704-726.

Svanbäck, R., and D. I. Bolnick. 2005. Intraspecific competition affects the strength of individual specialization: an optimal diet theory method. Evolutionary Ecology Research 7:993-1012.

Svanbäck, R., and D. I. Bolnick. 2007. Intraspecific competition drives increased resource use diversity within a natural population. Proceedings of the Royal Society B Biological Sciences 274:839-844.

Sweatman, H. P. A. 1983. Influence of conspecifics on choice of settlement sites by larvae of two pomacentrid fishes (Dascyllus aruanus and D. reticulatus) on coral reefs. Marine Biology 75:225-230.

Trégouboff, G., and M. Rose. 1978a. "Manuel de Planctonologie Méditerranéenne, Tome I Texte". Edition du Centre National de la Recherche Scientifique, Paris.

Trégouboff, G., and M. Rose. 1978b. "Manuel de Planctonologie Méditerranéenne, Tome II Illustrations". Edition du Centre National de la Recherche Scientifique, Paris.

Webster, W. S., and M. A. Hixon. 2000. Mechanisms and individual consequences of intraspecific competition in a coral-reef fish. Marine Ecology Progress Series 196: 187-194.

White, J. W., and R. R. Warner. 2007. Behavioral and energetic costs of group membership in a coral reef fish. Oecologia 154:423-433. 